\title{
Urdimento
}

Revista de Estudos em Artes Cênicas

E-ISSN: 2358.6958

\section{Liberdade criativa atrás das grades: \\ Um mergulho na arte dentro dos presídios do Piauí}

Entrevista com: Valdsom Braga concedida à Érica Rodrigues Fontes

\section{Para citar este artigo:}

FONTES, Érica Rodrigues. Liberdade criativa atrás das grades: um mergulho na arte dentro dos presídios do Piauí. Entrevista com: Valdsom Braga. Urdimento, Florianópolis, v. 3, n. 39, nov./dez. 2020. 
Liberdade criativa atrás das grades: um mergulho na arte dentro dos presídios do Piauí

\author{
Entrevista com: Valdsom Braga concedida à Érica Rodrigues Fontes ${ }^{1}$
}

\begin{abstract}
Resumo
Valdsom Braga narra sobre sua experiência como Diretor de Arte nos presídios do estado do Piauí, de 19 de janeiro de 2016 a 19 de janeiro de 2019. Ele identifica a arte como ferramenta de mudança social e salienta que a sociedade deve ser treinada a aceitar, e não a excluir, pessoas privadas de liberdade. Valdsom compara ainda a situação dos presídios com a situação das escolas estaduais do Piauí, onde hoje é Diretor Artístico de projeto com enfoque na valorização da vida, combatendo amplamente o suicídio.
\end{abstract}

Palavras-chave: Teatro político. Arte e ativismo. Teatro nas prisões.

Creative Freedom behind Bars: A Dive in the Art of Prisons from Piaui State, in Brazil

\begin{abstract}
Valdsom Braga narrates his experience as Art Director at prisons in Piauí State, Brazil, from January 19 of 2016 to January 19, 2019. He identifies art as a tool for social change and highlights that society should be trained to accept, and not to exclude, people deprived from liberty. Valdsom also compares the situation in prisons to the situation in the state schools from Piauí, where he is currently the Art Director of a project focused on defending life and fighting suicide widely.
\end{abstract}

Keywords: Political theater. Art and Activism. Theater in Prisons.

\footnotetext{
${ }^{1}$ Possui graduação em Inglês e Literaturas de Língua Inglesa pela Universidade do Estado do Rio de Janeiro (1999), mestrado em Romance Languages/ Literatura Brasileira pela University of North Carolina at Chapel Hill (2003) e doutorado em Romance Languages e Performance de Literatura pela University of North Carolina at Chapel Hill (2005). Tem pós-doutorado em Estudos Teatrais pela Ryukoku Daigaku, Quioto, Japão (2020), tendo desenvolvido projeto sobre possibilidades de intercâmbio entre o teatro tradicional japonês (kyogen, comédia) e o Teatro Imagem de Augusto Boal. ericarodriguesfontes@gmail.com
} 
Libertad creativa detrás de las rejas: una inmersión en el arte de las prisiones del estado de Piauí, en Brasil

\section{Resumen}

Valdsom Braga narra sobre su experiencia como Director de Arte en las prisiones del estado de Piauí, desde 19 de enero de 2016 hasta 19 de enero de 2019. Valdsom identifica el arte como herramienta de cambio social y destaca que la sociedad debe ser entrenada para aceptar, y no excluir, personas privadas de libertad. Valdsom compara todavía la situación de las prisiones con la situación de las escuelas estatales de Piauí, donde hoy es Director Artístico de proyecto con enfoque en la valoración de la vida, combatiendo ampliamente el suicidio.

Palabras claves: Teatro político. Arte y activismo. Teatro en las prisiones. 
Valdsom Braga é licenciado em Educação Artística pela Universidade Federal do Piauí (UFPI), onde nos conhecemos em virtude de projetos conjuntos entre OS FEDERAIS (projeto de teatro coordenado por mim e ligado à Coordenação de Letras Estrangeiras) e o Departamento de Música (com o qual eu e Valdsom Braga trabalhamos no musical Se todos fosse iguais a você em 2013, sobre a vida e obra de Vinícius de Moraes, dirigido pelo Prof. Cássio Martins, doutorando em Educação pela Universidade de São Paulo (USP) e professor de violino da UFPI). Eu fazia a direção cênica e Valdsom foi o responsável pela cenografia do espetáculo. Mas dizer que Valdsom é cenógrafo é muito pouco. Como ele mesmo gosta de dizer, ele é artivista, um termo relativamente novo para designar quem é artista e ativista e percebe a arte sob profundo viés social e político. Também é homem de teatro. Nesse ponto nos alinhamos bastante e o foco dessa entrevista é precisamente a arte teatral.

O trabalho artístico de Valdsom assumiu proporções ainda maiores de janeiro de 2016 a janeiro de 2019, quando ele foi nomeado Diretor Artístico nos presídios do Piauí e teve a oportunidade de visitar todos os presídios deste estado. Antes dele o diretor Aci Campelo tentou realizar um trabalho que durou pouco mais de um mês, em virtude de os detentos necessitarem estar sempre algemados. Depois, a atriz Sandra Loyola desenvolveu um trabalho no presídio feminino por um ano. Atualmente, o trabalho de ressocialização através da arte está suspenso por tempo indeterminado. Por esse e vários outros motivos, os três anos de Valdsom à frente das artes no sistema prisional do Piauí são dignos de todos os registros possíveis. Baseando-se em histórias ouvidas e vividas por lá, Valdsom escreveu as seguintes peças: Cartas de minha vida (sete apresentações), Colcha de retalhos (quatro apresentações), Feitas para amar (duas apresentações), Justiça (três apresentações) e Pássaros que não voam (duas apresentações)². Foi também nesse contexto que surgiu o filme $A$ dor que mora em mim, único filme brasileiro cujo elenco é inteiramente composto por detentos.

${ }^{2}$ As apresentações aqui referidas foram feitas no Theatro 4 de Setembro, no centro de Teresina. 
Figura 1 - Equipe do musical Se todos fossem iguais a você, apresentado na UFPI em 2013. Valdsom Braga está à direita de blusa vermelha e Érica Fontes está à frente, segurando um boneco do Zé Carioca

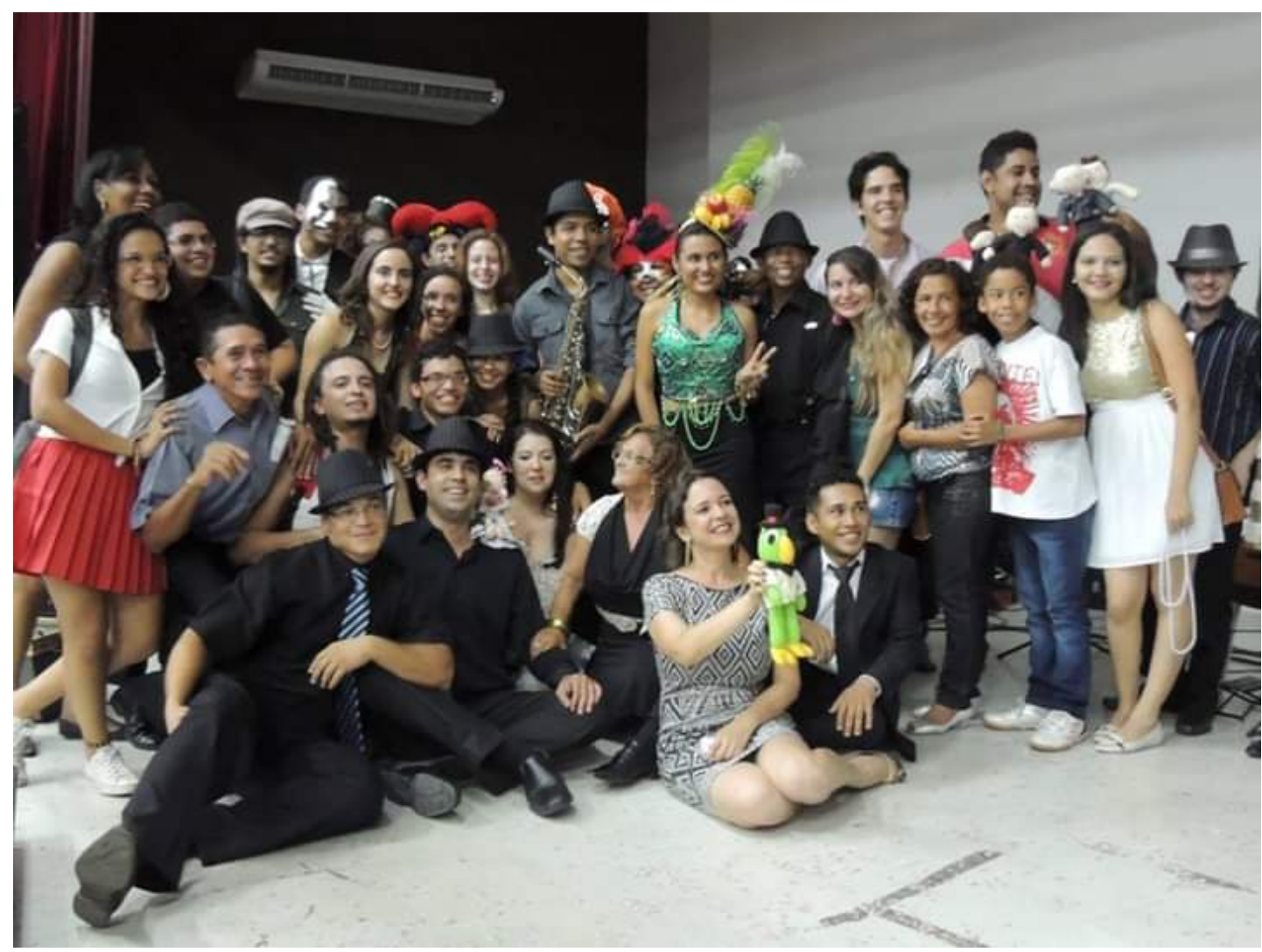

Acervo de Érica Rodrigues Fontes

A vida nos presídios apresenta um mundo à parte. Esse tipo de vida mostra um isolamento total em relação à sociedade. $\mathrm{E}$ há muito preconceito em torno disso. Por exemplo, há quem diga que não vai utilizar o serviço da Uber porque os empregados são perigosos, já que a empresa contrata ex-presidários, o que foi noticiado em telejornais. O interessante é que todas as pessoas têm o potencial de fazerem o bem e o mal. O que você acha dessa postura preconceituosa das pessoas, Valdsom?

A verdade é que existe todo um sistema que nutre essa mentalidade, essas crenças. Quando você liga o jornal, você nota que 80\% das notícias têm foco em tragédias e casos de polícia. E ainda tem um ditado que sempre é repetido: "Bandido bom é bandido morto". As pessoas dizem isso até o momento em que encontram alguém da família nessa condição [de bandido]. Aí elas mudam a posição e o discurso, porque não querem que alguém da família morra. Então o que acontece? A humanidade é individualista e acha que tem o direito de fazer 
justiça com as próprias mãos. Mas quando isso ocorre, a humanidade se torna tão criminosa quanto aquele que ela está agredindo. Temos que rever muitas coisas. A sociedade precisa analisar aquilo que está sendo apresentado e construído. Quando eu me coloco como artivista dos direitos humanos, é porque quero que a pessoas reflitam sobre como está nossa sociedade e o que está por trás de uma verdade que está sendo ditada por aí.

Quais eram suas expectativas em relação ao trabalho com pessoas privadas de liberdade, já que você conta no seu livro $A$ verdadeira liberdade [o livro não possui ISBN, mas consta na Biblioteca Nacional sob o registro 755.877] que tinha um sonho de trabalhar em presídios?

Eu já sabia que ali existia um público totalmente desassistido, totalmente mal julgado. Eu já tinha experiência e sempre quis trabalhar com grupos vulneráveis socialmente: povos sertanejos, indígenas, comunidades quilombolas e crianças refugiadas saindo da Guerra da Síria, para citar alguns exemplos. Mas quando eu me predispus a adentrar o sistema prisional eu já tinha uma base, uma noção do que eu iria encontrar lá dentro. Claro que além de pessoas que vão valorizar uma nova oportunidade, existem pessoas que são psicopatas, pessoas que não vão mudar nunca, pessoas que têm sede de fazer maldade. Mas isso não é novidade para essa geração contemporânea. Essa visão existe desde os primatas. Desde registros bíblicos, no primeiro livro, Gênesis, já há o assassinato de Abel pelo seu próprio irmão, Caim.

\section{Desde o início não estamos muito bem, né?}

Exatamente. Quando eu entro em um presídio, como bem observa Foucault³, estou em um local onde eu não tenho como extrair algo positivo. Ali é um local que vai oprimir as pessoas. Disso, eu já sabia. Quando eu iniciei os trabalhos, no presídio feminino com o projeto Mulheres de Aço e de Flores, disseram que eu tinha que dar aula para no máximo vinte meninas. E eu quebrei o protocolo. Solicitei uma reunião com todas. Então, setenta e cinco mulheres foram para um

${ }^{3}$ Valdsom refere-se aqui ao filósofo francês Michel Foucault. 
auditório me ouvir e no final eu fiz um convite: "Quem gostaria de participar?" e todas elas levantaram a mão. Eu não estava ali preocupado somente com a ferramenta dos jogos teatrais e da arte. Existia algo além dessa ferramenta que para mim era muito importante. Eu sabia que eu não ia produzir setenta e cinco atrizes. Nem todas seriam atrizes. Mas eu sabia que ali eu teria uma fonte de pesquisa muito rica que, com certeza, ia mudar toda a minha visão artística e minha interpretação da humanidade.

Você já sabia que seria difícil. Mas essas expectativas foram confirmadas, ou seja, teve muita surpresa nesse tipo de trabalho? Houve algo que você nunca imaginava que fosse acontecer?

Na verdade, eu já imaginava, mas as coisas são bem piores do que a gente imagina. Não é porque você visita um presídio que você pode dizer que conhece a realidade do sistema prisional. Passei por alguns presídios em outros estados também, incluindo presídios no Pará e Maranhão, o que me fez ver que cada presídio é único, cada um tem sua forma de lidar com questões importantes. Cada um tem suas regras, inclusive as regras das facções lá dentro também. Na verdade, são muitos detalhes a serem considerados. Eu me lembro que quando lancei meu livro em janeiro de 2018 e recebi um prêmio na Câmara Municipal do Rio ${ }^{4}$, eu conheci Marielle Franco, que foi brutalmente assassinada dois meses depois. Antes desse momento, eu tive a oportunidade de conversar com ela sobre algumas ações que ela fazia em uma favela e o quanto ela era querida por aquele povo. Eu notei que em suas redes sociais ela denunciava algumas questões e falava abertamente sobre o que via nas facções criminosas. E uma vez perguntaram para ela: "Marielle, você sabe que o que você faz é muito sério e pode custar sua própria vida?" E ela deu uma resposta que eu nunca esperava ouvir: "Nem que isso custe minha própria vida, eu não vou calar a minha voz". Diante disso, cabe refletirmos sobre quantas vezes nos calamos com relação àquilo que achamos correto, por termos medo do que os outros vão pensar. Os frutos do trabalho é que vão calar a boca de quem não acredita em nós. No meu caso, foram

${ }^{4}$ Em 2018, na Câmara Municipal do Rio, Valdsom lançou A verdadeira liberdade e recebeu um prêmio por seu trabalho de ressocialização. 


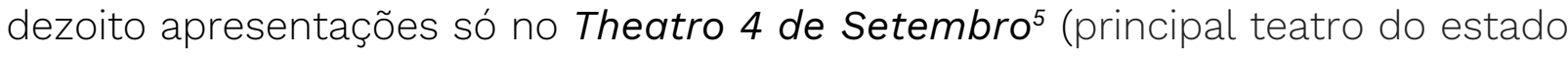
do Piauí). Foi incrível poder levar essas pessoas, e muitas nunca tinham entrado em um teatro, para pisarem em um palco e usarem sua voz para trazer uma mensagem para a sociedade. Jamais vou me esquecer disso. Isso é quebrar tabu. Isso é ser corajoso. Graças a Deus eu tive o apoio do Secretário de Justiça, à época o Sr. Daniel Oliveira. Outra oportunidade aconteceu em 20 de dezembro de 2017 no Parque da Cidadania (um dos principais parques públicos de Teresina), quando fizemos o musical de Natal Siga a estrela, natal da cidade, com os detentos e três mil pessoas na plateia. Foi muita ousadia.

Como diretora e coordenadora de projetos de teatro, eu tenho a curiosidade de saber como era a rotina de atividade teatral. No livro você conta que no presídio masculino inicialmente os detentos queriam te contar episódios da vida deles, mas você só queria saber o nome deles. É interessante notar que às vezes pessoas que são privadas de liberdade vão te contar coisas para que você não goste delas, algo do tipo: "Já vou te avisar logo que sou perigoso, perigosa, você não vai dar jeito em mim. Eu fiz isso e aquilo. Já matei alguém”. Achei muito positivo você ter dito que não queria saber nada. Só queria saber o nome deles. Quanto tempo durava a prática e o que acontecia lá? O que você fazia com elas e eles?

Eram duas horas de aula, tanto pela manhã quanto pela tarde. Eu tive que dividir as turmas no presídio feminino porque eram muitas detentas. Depois da penitenciária feminina, o projeto se estendeu para o Irmão Guido e para a Casa de Custódia [presídios masculinos] e lá recebeu o nome de Espelho da Realidade. Quando eu assumi o cargo de diretor, viajei por todos os presídios do estado, fazendo conferências e oficinas ou levando alguns deles, de Teresina, para fazerem apresentação nos presídios do interior. Sobre a metodologia: eu enfatizava meus relatos de experiência. Claro que toda vez que alguém ouve um relato sincero, se sente, de certa forma, na obrigação [moral] de também compartilhar algo de sua própria experiência. Há uma aproximação muito grande - é o rapport. Eles tinham necessidade de falar de suas dores, de sua vida, de contar seus crimes. Eu já sabia que alguns gostam de aumentar um pouco suas histórias para se sentirem

${ }^{5}$ A primeira apresentação de Cartas de minha vida ocorreu em 02 de março de 2016 no Theatro 4 de Setembro. 
protegidos. Por exemplo, se você matou oito pessoas, acaba dizendo que já matou trinta e duas. É uma forma de chamar a atenção.

\section{É para dizer "Eu sou mau, eu sou má".}

Sim, e é uma forma de se proteger dentro daquela realidade que é um outro universo. Mas eu tive que me preparar através de alguns livros que li. Nana Queiroz, no livro Presos que menstruam, fala sobre as três verdades: a verdade de quem sofreu a agressão, a verdade de quem cometeu o crime e a verdade da Justiça. A pessoa que trabalha com eles precisa ter uma distância analítica e observar essas três verdades. No começo eu me envolvia muito sentimentalmente com os alunos e alunas. Eu voltava para casa muito mal com os relatos. Por exemplo, uma vez uma aluna que tinha o laudo de esquizofrenia me relatou que ouvia vozes e que contou isso à família dela. As vozes diziam que ela tinha que executar um dos filhos. E ela pegou um travesseiro e matou um deles. Por que a família não a ajudou com relação a essa doença? Se a família tivesse sido mais atenta, teria evitado essa tragédia. Porque quando alguém toma uma medicação, ela não oferece risco a ninguém. Você nota que há muita falta de informação e entendimento. E você vê que cada história é uma história. E, por isso, eu sempre fazia jogos teatrais trazendo a situação cênica para a realidade delas. Eu pedia para que elas imaginassem cenas baseadas no que eu ouvia delas. Por exemplo: "Você está numa praça deitada num papelão, você já tinha usado droga o dia inteiro. De repente chega seu pai que você não vê há três semanas. Eu vou fazer essa cena agora. Eu faço o pai e você faz a filha. Você consegue visualizar esse ambiente? Você consegue se sentir nesse ambiente?"

Interessante você fazer essa contextualização em exercícios tradicionais de teatro, usando a realidade dessas alunas.

Eu tinha que usar as gírias deles também, chamando os alunos e alunas de “maluco, louco, louca”. Eu tinha que aprender a falar assim: de uma forma direta e me aproximando deles. Foi um desafio. Mas todas as vezes que a gente construía uma cena, o que me chamava mais atenção era que tinha resposta imediata. Era 
muito comum eles dizerem: "Professor, aconteceu isso comigo. Você está relatando a minha vida e minha história. Quem falou para você da minha vida?". Tudo isso vai se tornando um ambiente no qual eles se sentem à vontade. E um detalhe: quando eu fiz a construção das peças, fiquei impressionado com a quantidade de material de pesquisa que eu já tinha. Era tanta informação, que não tinha como você não criar um texto, um poema. Os vários espetáculos foram todos extraídos de dentro da vivência.

As aulas tinham sempre o objetivo de preparar os alunos para os espetáculos? Você já tinha em mente desde o início mais ou menos o que você queria ver como resultado, apesar de não conhecer as pessoas com as quais iria trabalhar?

Eu tinha um planejamento por vários motivos. Um deles é a rotatividade dentro do sistema prisional, que é bastante intensa. Tinha época que eu tinha setenta e duas alunas e época que eu tinha cinquenta. Entra muita gente e sai muita gente. Eu tinha uma responsabilidade, como artista, de desenvolver um conteúdo de aula que em duas horas seria único porque nem sempre havia a opção de continuidade. Eu pegava temas específicos. Tinha uma aula que eu chamava de Paternidade e na qual eu falava através de jogos teatrais sobre a importância da figura paterna na vida do ser humano. 70\% das alunas já tinham problema na área familiar e especificamente com o pai porque tinham sido vítimas de abandono, rejeição. Eu creio que todos os bloqueios e vícios surgem de valores essenciais desconstruídos. Era preciso usar a arte e uma análise de saúde mental para ver o que eles precisavam ter como resposta. Diante disso eu fazia uma aula que era uma forma de eles olharem para si, analisarem seus valores e entenderem que a dor do passado trouxe um peso para a vida atual a ponto de eles e elas não conseguirem viver algo novo porque estavam presos, presas na carência. Muitas mulheres que vivem nas ruas acabam se prostituindo por drogas. Infelizmente, a prostituição é algo a que os brasileiros e brasileiras recorrem também fora do Brasil para terem seu sustento.

Falando sobre outros países, você pode contar sobre a experiência de montar Cartas de Paulo na Turquia e como isso influenciou o trabalho com os detentos? 
Fiquei lá durante um mês. E fizemos o espetáculo em uma igreja. É importante ressaltar que não há tanta abertura assim para igrejas cristãs na Turquia. Havia pessoas do mundo todo e a porta principal ficava meio fechada. Eu fazia o espetáculo e tinha que pausar para ser traduzido para outras línguas. Depois da tradução, a ação retornava.

\section{Que interessante. Nunca vi ou fiz nada assim na vida.}

Tinha cinco línguas representadas e eu falando só o português. Para mim foi uma experiência fundamental porque o território turco foi o território onde Paulo nasceu e o lugar onde ele mais andou, o que teve um peso muito grande e foi uma responsabilidade. Alguns pontos do espetáculo foram mudados depois, quando ele entrou em cartaz no Brasil. Na Turquia eu usava a minha figura de um homem de trinta e poucos e anos, barbudo. Essa experiência influenciou o trabalho Justiça, do qual falarei mais depois, com vários personagens bíblicos que tiveram problemas com a justiça.

Na verdade, seus traços até um pouco turcos devem ter ajudado também.

Bem turcos. Por isso ninguém me parava, ninguém mexia comigo. Essa era a parte positiva. Mas quando eu retornei ao Brasil e tive vontade de estrear o espetáculo no Theatro 4 de Setembro, eu tive contato com o Cid Moreira ${ }^{6}$ que conhece realmente a Bíblia e história bíblica. Ele não é apenas uma pessoa que tem uma voz belíssima e gravou a Bíblia em áudio. Então, ele perguntou se eu sabia qual era a idade de Paulo quando ele escreveu as últimas cartas, que são o foco do espetáculo. E eu não sabia. O Cid respondeu: "Olha, o Paulo deveria ter uns oitenta e poucos anos e você está com rostinho de garoto. Você precisa fazer uma caracterização, mudar o seu rosto para ficar mais fiel à história”. Depois disso ele me deu algumas dicas e eu me caracterizei como um homem mais velho.

${ }^{6}$ Nascido em São Paulo, em 1927, Cid Moreira foi apresentador do Jornal Nacional, transmitido pela Rede Globo de Televisão, de 1969 a 1996 e é um dos jornalistas mais famosos do Brasil. 
Que ótima essa contribuição do Cid Moreira! Foi muito bom você ter mais algumas informações, embora a arte permita algumas liberdades no processo criativo e você nem precise representar exatamente tudo como aconteceu. Mas a informação foi boa para trazer uma espécie de verdade para o teu espetáculo, se esse era o teu objetivo.

Eu amo quando tem pesquisa. Quando podemos mostrar artisticamente algo que é próximo aos registros históricos. Eu faço essa peça inclinando-me sobre um pergaminho de 7 metros que foi confeccionado por um falante de árabe e contém trechos de Coríntios nessa língua.

Ainda com relação ao trabalho nos presídios, você finalizava o texto teatral, apesar de ser a história dos detentos e detentas? Em outras palavras, era você que fazia a costura do texto com as diversas narrativas oriundas das diversas experiências deles?

Todos os textos dos espetáculos eram produzidos por mim, baseados na vivência das aulas e nas histórias de vida que eles compartilhavam. A maioria deles apresentava [uma releitura de] sua própria vida em cena. No espetáculo Justiça, por exemplo, que tem alguns personagens da Bíblia injustiçados à sua época, eu fazia um paralelo entre a história bíblica e o momento que os detentos estavam vivendo. Sobre Judas, que foi o traidor, analisávamos sobre quantas vezes a sociedade também trai.

Eram tópicos muito fortes. É impossível não haver um envolvimento das pessoas durante o trabalho. Fale mais um pouco sobre essa ligação emocional entre você, como professor, e os alunos, no contexto de um presídio. Existia uma dependência, porque muitas vezes você em algum momento pode ser a única pessoa que deu valor àquele ser humano apesar do crime (ou crimes) que cometeu?

Eu tive muitos conflitos com relação à paternidade na minha infância. Eu não tive um pai presente. Meu pai era viciado em álcool. Eu precisava de referências na paternidade. Isso influenciou o meu trabalho tanto nas escolas quanto nos presídios. Há homens mais velhos do que eu que se aproximam de mim e perguntam se podem me chamar de pai porque querem ter a sensação de convívio com a figura paterna. Eu acho isso muito restaurador. É como diz aquela canção do Whindersson Nunes, "Girassol": "Eu quero ser curado para curar 
também”. Há esse processo curador para mim e para eles. Eu creio que essa figura de paternidade acaba curando muitas feridas. Para mim é um privilégio. Eu amava ser chamado assim e ainda sou por muitos que saíram. E quando eu ouço alguém me chamando assim, eu já fico muito positivamente tocado. Existe uma ligação que carregamos para sempre. Eu não acho que isso é destrutivo. Pelo contrário, eu vejo mais como positivo do que negativo. Eu fico maravilhado. Na minha nova função, eu viajo pelas escolas do estado do Piauí também. E é muito comum alguns alunos pedirem para me chamar de pai. Eu já sou até acostumado com isso.

Eu acho um pouco perigosa essa ligação tão profunda. Mas a tua realidade dentro dos presídios era bem peculiar. E de fato é bem improvável não termos laços com aqueles que convivemos tanto através do processo educativo. Às vezes há histórias e compartilhamentos de sofrimentos que nos marcam muito. É inevitável ser tocado pela dor do outro ser humano. Indo para a nossa próxima pergunta, há alunos que saíram dos presídios, das suas aulas de teatro e continuam sendo artistas?

Sim, há. Por exemplo, a Rafaela Gregório, que era uma traficante muito temida, mudou de vida completamente. Através de pessoas que foram fazer ações dentro de comunidades de apoio a moradores de rua no centro da cidade de Teresina, eu soube que a Rafaela faz encenações públicas de trechos do espetáculo Cartas de minha vida.

Que coisa maravilhosa!

Recentemente outra ex-detenta entrou em contato comigo e falou que também está encenando seu texto do espetáculo para pessoas em vulnerabilidade social. Hoje elas falam o texto bem melhor do que antes, hoje elas interpretam também melhor. O trabalho teatral virou para elas um escape, uma forma de se esvaziarem de algo e de passarem uma mensagem através da arte.

No teatro há essa relação visceral com as pessoas: é uma troca energética muito forte. $O$ grupo de pessoas de teatro talvez seja o grupo mais sensibilizado nesse momento de pandemia, porque as atividades estão completamente suspensas, embora haja paliativos. É uma dor tão grande não poder vivenciar essa troca agora. No teatro, ao vivo, há uma comunicação profética muito poderosa, 
independentemente de religião. Hoje você trabalha nas escolas estaduais do Piauí principalmente com valorização à vida e prevenção ao suicídio. Quais são as semelhanças e diferenças vistas entre esses dois públicos - dos presídios e das escolas?

Existem semelhanças, porque os conflitos urbanos pelos quais eles passam são muito parecidos - problemas com drogas, abandono. Infelizmente hoje quem está estudando dentro de uma escola pública, considerando o contexto no qual está inserido ou inserida, poderá amanhã estar dentro do sistema prisional. Na periferia, há o tráfico constante. Tem jovens que são ensinados a traficarem pelos próprios pais. Quando o pai precisa fazer alguma coisa não relacionada ao trabalho é o filho que fica em casa vendendo droga. Os dilemas são muito parecidos. Não vejo muita diferença.

É muito marcante você ter visto o processo de libertação de muitos detentos e detentas e ao mesmo tempo acompanhar o processo que está encarcerando muitos jovens psicologicamente e que poderá levá-los ao aprisionamento físico. Eu nunca tinha parado para pensar nisso.

Eu amo meu trabalho porque é um trabalho de intervenção. É um trabalho de combate ao suicídio, é um trabalho de combate ao cárcere. Meu trabalho também é fazer com que as pessoas não cheguem àquele local. É muito mais provável que, ao ficar detida em um presídio, a pessoa saia muito pior do que entrou. É preciso evitar, portanto, esse encarceramento. Fico muito grato, porque eu posso efetivamente fazer algo contra o suicídio. Por que eu estou falando isso? Porque eu vejo muitas pessoas falarem sobre o suicídio, levantarem dados sobre o assunto. Mas realmente poucas fazem um trabalho de prevenção, falando sobre os desafios diários da vida. Os desafios são constantes - desde a hora que acordamos até a hora que vamos dormir. A diferença está nas ferramentas que podemos usar para vivermos bem, para pensarmos de forma positiva com relação à solução de conflitos da vida.

Realmente é muito mais comum vermos as pessoas chorarem pelo leite derramado do que prevenirem uma tragédia. Você prova que pode existir arte em tudo o que é feito, embora às vezes alguns artistas sejam tratados como divindades. Boal também defende que todos podemos ser atores e atrizes de nossas próprias 
histórias. No caso dele era uma questão mais política. Mas vejo essa dessacralização da arte no teu trabalho, da mesma forma. Você acha que ainda há muito a ser feito para que as pessoas sejam libertas através da arte?

Eu creio que a arte precisa ser motivada por um objetivo social. A arte precisa marcar uma geração e deixar um legado. Eu não gosto de espetáculos que não provocam uma reflexão social. Eu me recordo que seu último espetáculo falou sobre a questão da violência nas escolas.

Sim. O espetáculo Suzanos ${ }^{7}$ baseado na tragédia ocorrida em Suzano que também usava cantigas de roda como trilha sonora. Era uma espécie de pergunta sobre o que estamos nos tornando e os motivos dessa transformação.

Pois é, esse espetáculo faz você refletir sobre a vida, sobre como você lida com o outro. Existia a diretora que tinha uma vida oculta, que provocava os alunos. Foi um espetáculo que me marcou, que me fez refletir e isso é benéfico. Eu defendo a arte com propósito. Todo o artista tem ferramenta e sensibilidade para provocar uma reflexão, uma mudança social. A arte sempre traz revoluções e mudanças.

A arte comunica e cria. Não é inacessível. É algo que muitas pessoas ou todas as pessoas podem fazer se tiverem essa consciência. Já vi pessoas serem totalmente destravadas através do teatro. Em Cartas de minha vida, havia uma atriz maravilhosa e que nunca tinha passado por um treino teatral tradicional. Era uma atriz impressionante, ainda detenta à época. Elza Bellini, né?

A Elza Bellini impressionava realmente a todos.

Quais são seus projetos como artivista? Sei que você é um homem com muitas ideias e incansável energia.

Eu tenho muitos projetos, porque no dia que não tiver mais projetos eu estarei depressivo e triste. Nessa pandemia eu escrevi três livros, já lancei um deles $A$

O espetáculo Suzanos foi desenvolvido na UFPI, pelo projeto de extensão Os Federais, e é baseado na tragédia ocorrida em uma escola em Suzano, em março de 2019, quando dois ex-alunos assassinaram oito pessoas no local e foram mortos. Através do espetáculo, procurou-se questionar como estamos vivendo a educação no Brasil e a violência que tem sido gerada. Por isso o nome Suzanos, com "s" generaliza o ocorrido e mostra que muitas instituições educacionais podem se tornar também vítimas de seu próprio sistema. 
chave da mente que está na minha bio do Instagram @valdsombraga. Eu tenho o projeto O pescador de sonhos, através do qual eu me apresento de cabelo grande e falo sobre a valorização à vida. Através desse projeto, eu tenho feito muitos encontros virtuais com alunos e professores. Fazemos uma roda de conversa e falamos sobre vários assuntos, com foco em saúde mental e combate à ansiedade, depressão...Esses são os projetos virtuais que estou fazendo no momento, porque presencialmente eles não podem ocorrer. Eu tenho contatos de várias meninas que encenaram Cartas de minha vida e tenho o sonho de fazer uma comemoração dos cinco anos do espetáculo para que ao final as meninas relatem como está a vida delas após o sistema prisional.

\section{Seria outro texto?}

É o mesmo texto com adaptações que incluem o que elas estão fazendo hoje. Eu pretendo homenagear a Bianca, que foi assassinada há dois anos. Ela tinha apenas vinte e dois anos. Eu gostaria de trazer o figurino dela e a narrativa dela para resgatar sua participação in memoriam. E quero falar sobre o que aconteceu com ela e sobre como algumas dessas pessoas com as quais eu trabalhei não tiveram um final feliz.

Você está investindo em seres humanos e não sabe o que irá acontecer. Sempre é uma caixinha de surpresas.

E eu quero deixar esse espetáculo salvo no meu canal do YouTube. Quero que as pessoas vejam se há ou não há ressocialização. Muitas pessoas não acreditam nesse segundo momento de ex-detentos, ainda há esse tabu.

Queria finalizar com informações sobre o filme que você dirigiu: $A$ dor que mora em mim.

Esse é o primeiro filme feito por atores em cárcere no Brasil e talvez no mundo. São os próprios detentos e detentas interpretando sua história e realidade, diferentemente de Carandiru, sucesso do cinema brasileiro, que fala do sistema 
prisional, mas não por detentos. A dor que mora em mim está disponível no YouTube .

\section{Muitíssimo obrigada pelo seu trabalho e compartilhamento de experiência e ideias. Foi um grande prazer.}

Eu que agradeço.

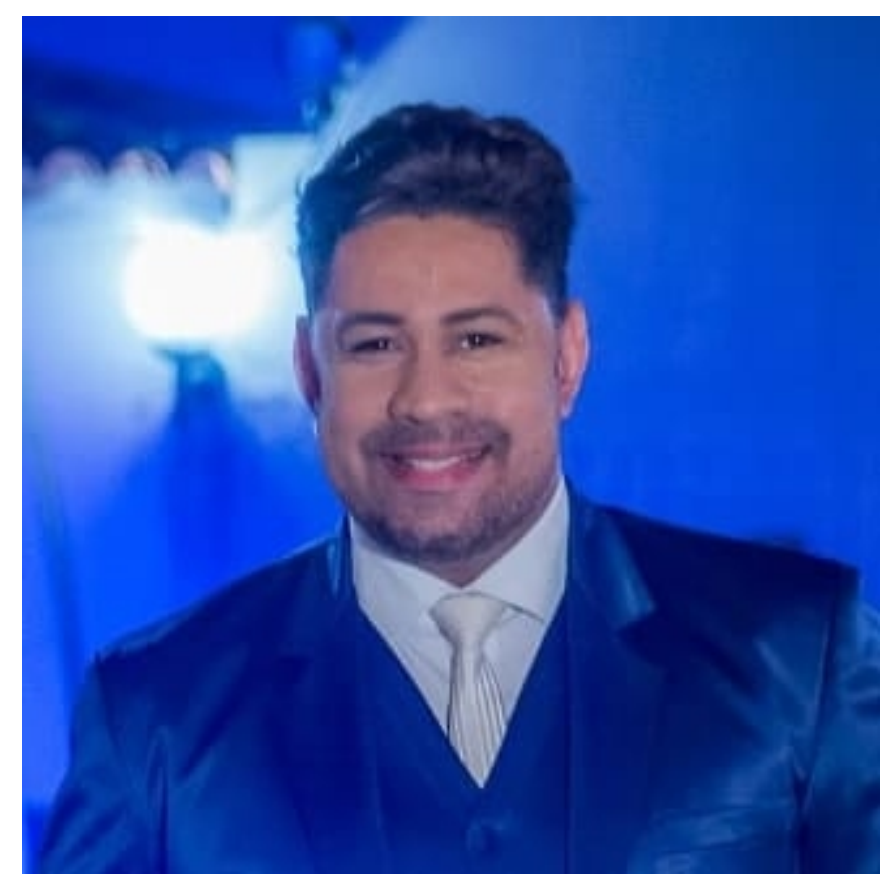

8 O filme, gravado em 48 horas, faz uma documentação ficcionalizada das histórias vividas pelos detentos que fizeram parte do projeto de ressocialização, foi gravado em 48 horas e tem o centro da cidade de Teresina e espaços dos presídios como locações principais. Ele pode ser visto na íntegra no link a seguir: https://www.youtube.com/watch?v=WZqNxzDPpqY 
Figura 3 - Primeira apresentação de Cartas de minha vida em 02 de março de 2016, no Theatro 4 de Setembro

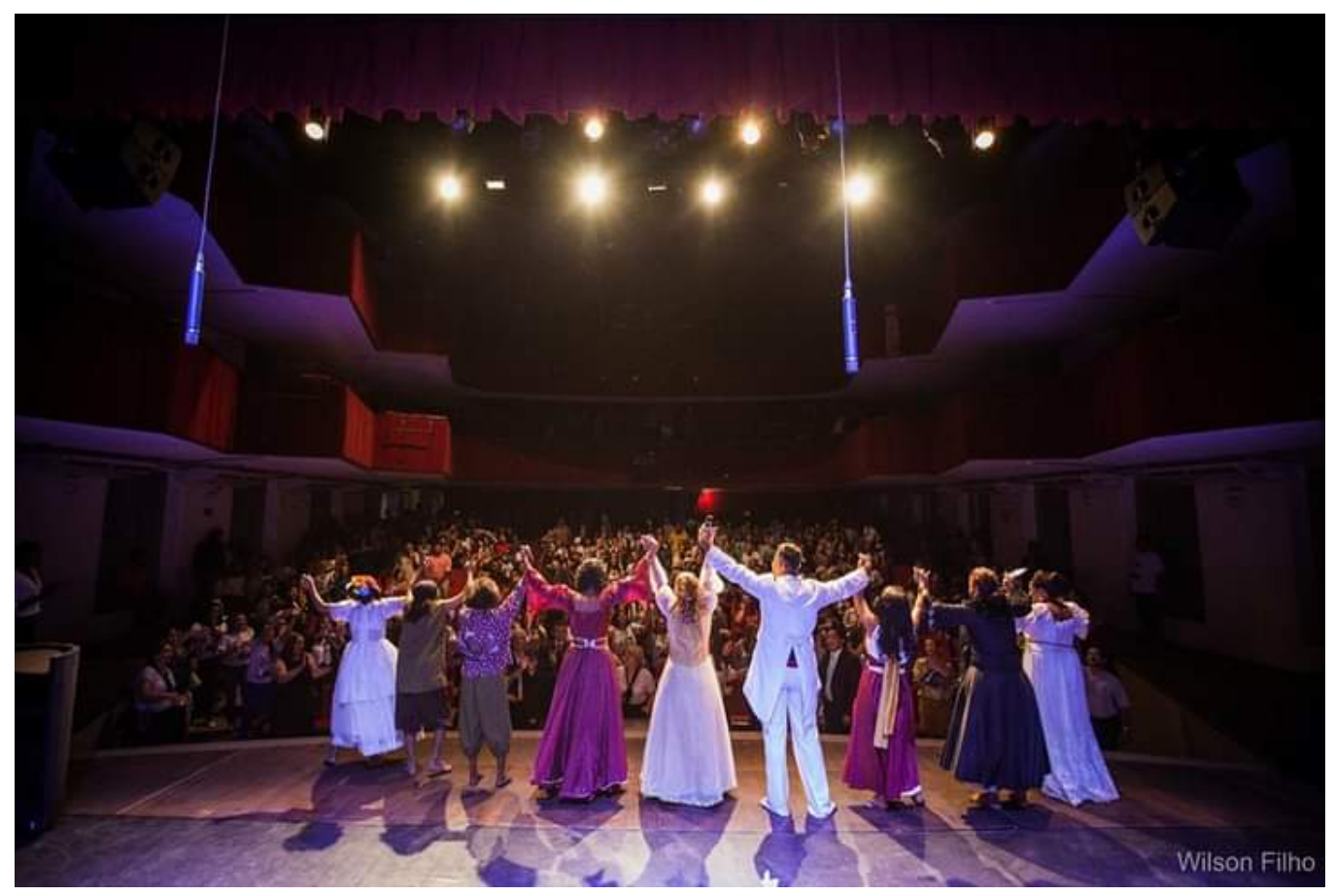

Figura 4 - Apresentação de Cartas de minha vida presídio feminino de Teresina, em 08 de março de 2016 


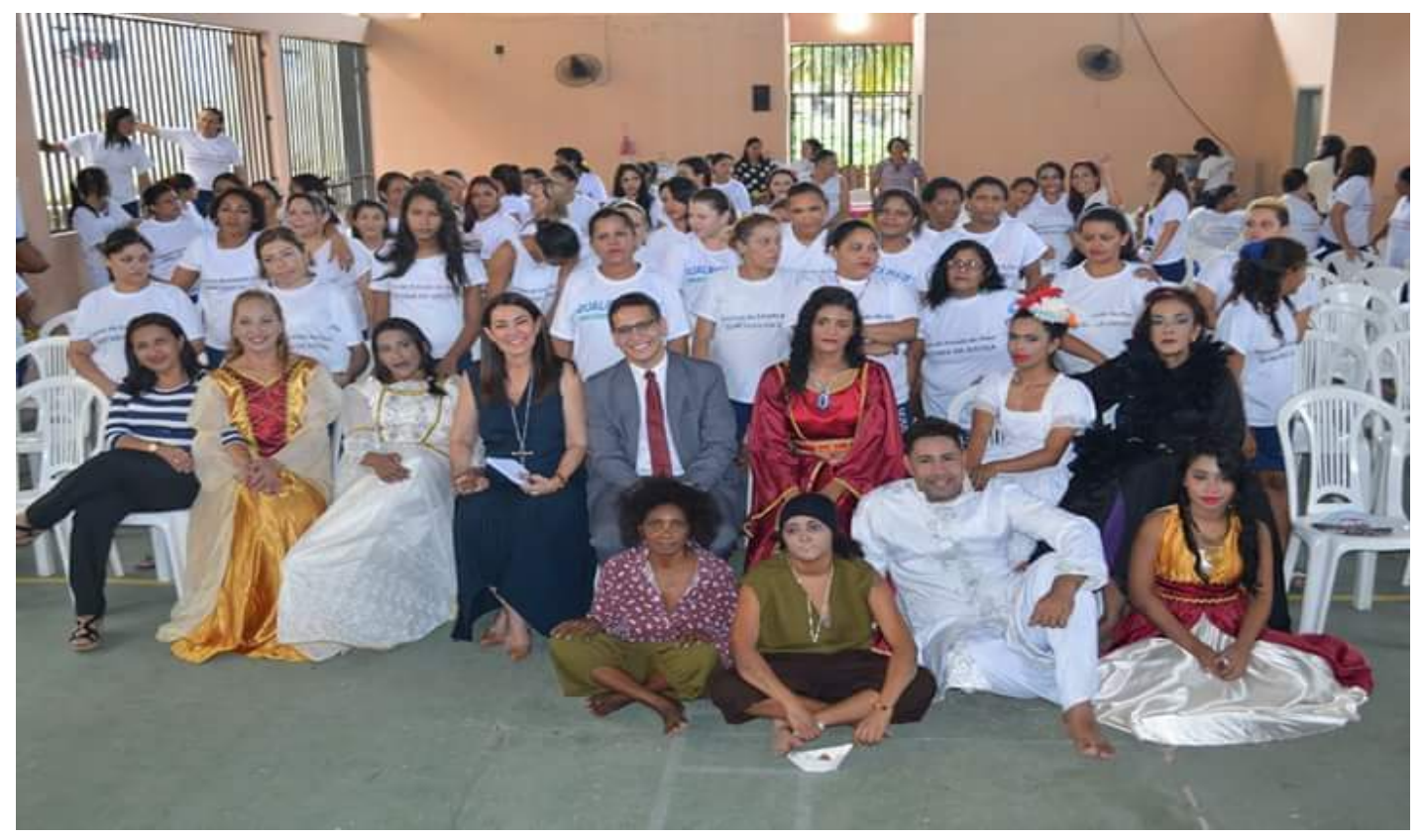

\section{Referências}

BOAL, Augusto. Teatro do oprimido e outras poéticas políticas. São Paulo: Editora 34, 2019.

FOUCAULT, Michel. Vigiar e punir: o nascimento da prisão. Rio de Janeiro: Vozes, 2014.

QUEIROZ, Nana. Presos que menstruam. São Paulo: Record, 2015.

Recebido em: 16/10/2020

Aprovado em: 19/10/2020 
Universidade do Estado de Santa Catarina - UDESC Programa de Pós-Graduação em Teatro - PPGT Centro de Arte - CEART

Urdimento - Revista de Estudos em Artes Cênicas Urdimento.ceart@udesc.br 